\title{
Anxiety and depression during the COVID- 19 pandemic in Kuwait: the importance of physical activity
}

\author{
Khaled E. Alsharji(D)
}

\begin{abstract}
Background: In Kuwait, as in much of the world, COVID-19 epidemic has been spreading since February 2020. The government of Kuwait has taken several measures to minimize virus spread. The epidemic and measures to contain it will likely psychologically influence individuals. This study investigated the prevalence of anxiety and depression symptoms in Kuwaiti nationals and expats. The study's secondary aim was to identify the association between sociodemographic characteristics and physical activity (PA) engagement, with psychological disorders such as anxiety and depression during the COVID-19 pandemic in Kuwait. A two-section survey was used to examine sociodemographic characteristics and PA engagement, and generalized anxiety (GAD-7) and depression symptoms (PHQ-9).

Results: Results of this study indicated that $53.7 \%$ and $59.6 \%$ of the respondents experienced anxiety and depression. The multiple regression models significantly predicted anxiety and depression $(P<0.001)$. In addition, PA, gender, education, and age were significantly associated with anxiety $(P<.05)$, while PA, gender, age, and marital status were significantly associated with depression $(P<.05)$.
\end{abstract}

Conclusions: Findings suggest that the COVID-19 outbreak may have a greater psychological impact on women, younger individuals, married people, and individuals with a bachelor's degree. However, regular PA appears to be an important immediate and long-term factor in reducing symptoms of anxiety and depression during an epidemic.

Keywords: Anxiety, Depression, COVID-19, Physical activity, Physical inactivity

\section{Background}

The novel coronavirus 19 (COVID-19) first emerged in December 2019 in Wuhan, China [34]. Subsequently, it has spread fiercely around the world compelling the World Health Organization (WHO) on March 11, 2020, to declare the COVID-19 outbreak as a pandemic. The first confirmed case in Kuwait was announced on February 24, 2020, while the first death was reported on April 4, 2020. As of 12 August, there were 73,785 confirmed cases of COVID-19, with 65,451 recoveries and 489 deaths.

COVID-19 is the most recently discovered member of several coronaviruses with many similarities with severe acute respiratory syndrome (SARS) and Middle East

Correspondence: ke.alsharji@paaet.edu.kw

Department of Physical Education \& Sports, College of Basic Education,

Public Authority for Applied Education \& Training, Kuwait City, Kuwait respiratory syndrome (MERS). The virus is highly contagious and infectious affecting all segments of the population. However, the elderly and patients with preexisting conditions including diabetes and cardiovascular, respiratory, and immune diseases are more susceptible and experience more severe symptoms. The virus is transmitted via close contact $(<2.0 \mathrm{~m})$, droplets (from coughing/sneezing), and in rare cases airborne. It attacks primarily the respiratory system causing a wide range of cold-like symptoms, most common are fever, cough, sneeze, runny nose, sore throat, chills, headache, loss of taste or smell, tiredness, muscle aches, and chest pain. However, in some cases vulnerable patients may experience shortness/difficulty of breathing and possible fatality.

\section{Springer Open}

(c) The Author(s). 2020 Open Access This article is licensed under a Creative Commons Attribution 4.0 International License, which permits use, sharing, adaptation, distribution and reproduction in any medium or format, as long as you give appropriate credit to the original author(s) and the source, provide a link to the Creative Commons licence, and indicate if changes were made. The images or other third party material in this article are included in the article's Creative Commons licence, unless indicated otherwise in a credit line to the material. If material is not included in the article's Creative Commons licence and your intended use is not permitted by statutory regulation or exceeds the permitted use, you will need to obtain permission directly from the copyright holder. To view a copy of this licence, visit http://creativecommons.org/licenses/by/4.0/. 
After a rapid increase in cases, the Kuwaiti government implemented rigorous measures to intercept the virus spread. The Kuwaiti government suspended work, schools, universities, public events, social gathering, and closed boarders and public parks. Subsequently constraining people to home confinement and the entire country was lockdown. These measures can lead to social isolation and loneliness [26]. However, among the procedures, the government allowed a daily $2 \mathrm{~h}$ of grace period, during which many people may use this time to engage in physical activity (PA).

The combination of the virus complications, implemented governmental procedures, and the absence of pharmacological interventions, most likely people would experience emotional, psychological, and behavioral changes [6, 25]. Cao et al. [9] argued that when faced with highly contagious diseases people may experience unbearable psychological distress that may trigger harmful behaviors [23]. Subsequently, these feelings can lead to anxiety, depression, and poor mental health, and, in some cases, suicidal ideation [7, 26]. In fact, in a recent study, $53.8 \%$ reported moderate/severe psychological effect; $28.8 \%$ reported moderate/severe anxiety symptoms; $16.5 \%$ reported moderate/severe depressive symptoms; and $8.1 \%$ reported moderate/severe stress levels [31].

Regular participation in PA is frequently cited as the first step in lifestyle modifications to prevent and manage chronic disease [4], including psychological disorders. Regular participation in PA seems to improve selfefficacy [22], while reducing anxiety [17], depression $[16]$, and negative moods $[8,11]$. The global standard recommendations for $\mathrm{PA}-150 \mathrm{~min} /$ week of moderate PA or $75 \mathrm{~min} /$ week vigorous PA [33] —is effective in treating psychological disorders such as anxiety, depression, stress, and panic. Therefore, given these mental and psychological benefits, PA should be incorporated into epidemic risk reduction programs. Even during a quarantine, or total curfew, PA can be carried out at home [20].

At the time of this study, the COVID-19 outbreak curve indicated that Kuwait had approached the epidemic peak. Consequently, symptoms of psychological disorders (i.e., anxiety and depression) have likely already emerged [31]. PA, as indicated earlier, could be an important method for reducing these symptoms. Therefore, this study aimed to investigate the prevalence of generalized anxiety and depression symptoms in Kuwaiti nationals and expats. The study's secondary aim was to identify the association between sociodemographic characteristics and PA engagement, with psychological disorders such as anxiety and depression during the COVID19 pandemic in Kuwait. The author expects to increase prevalence of anxiety and depression during COVID-19 in Kuwait. Additionally, age, gender, marital status, and occupations would be associated with psychological status among the participants.

\section{Methods \\ Participants and study design}

A web-based cross-sectional survey was first disseminated via official emails to the Public Authority for Applied Education and Training (PAAET), the largest higher education entity in Kuwait and includes institutions from every governorate in the country. PAAET's email list includes current/former students, teachers, trainers, faculty members, and current and retired employees. It therefore offers a representative microcosm of Kuwaiti society. The survey link was sent through social media (Twitter, Facebook, and Instagram). The survey was administered via the Google Form platform and was anonymous to ensure confidentiality and reliability of the data. Respondents were selected by snowball sampling, and each respondent was encouraged to forward the link to other family members, friends, and colleagues. The survey was conducted from 21 June to 11 July.

\section{Instruments}

The survey is divided into two sections: (1) sociodemographic characteristics and PA engagement and (2) level of anxiety and depression. The sociodemographic characteristics and PA engagement were obtained with questions about gender (male or female), age, marital status (married or unmarried), occupation (employed, student, retired, or unemployed), and education level (high school or less, bachelor's, or graduate degree). Additionally, in order to obtain PA engagement, the participants were asked to respond yes/no to two inquiries since the emergence of COVID-19. These inquiries were as follows: I do moderate ( $\geq 150 \mathrm{~min} /$ week) or vigorous physical activities ( $\geq 75 \mathrm{~min} /$ week). These responses were used to determine whether or not the respondents met the global PA standards [33].

The Patient Health Questionnaire (PHQ) is a selfadministrated instrument with six modules measuring six disorders: depression (PHQ-9), generalized anxiety (GAD-7), panic, somatization, and eating and alcohol abuse disorders [28]. Respondents completed the Arabic versions of GAD-7 and PHQ-9 [2] to assess anxiety and depression, respectively. The GAD-7 has been translated to Arabic, found reliable (Cronbach's alpha $=0.763$ ), and used extensively in several Arab countries [2]. Respondents reported anxiety symptoms using a 4-item Likert scale ranging from 0 (not at all) to 3 (nearly every day). Seven questions assessed the frequency of anxiety symptoms over the past weeks with a total score ranged from 0 to 21 (normal $=0-4 ;$ mild $=5-9$; moderate $=10-14$; severe $=15-21)$. The questions inquired about feeling nervous, anxious, on edge, or worrying about different 
things; feeling restless so that it is hard to sit still; getting tired very easily; muscle tension, aches, or soreness; trouble falling asleep or staying asleep; trouble concentrating on things, such as reading a book or watching TV; and becoming easily annoyed or irritable $[2,28]$.

Similarly, the PHQ-9 has also been translated, found reliable (Cronbach's alpha $=0.857$ ), and used extensively in the Arab countries [2] and been found to be reliable. Respondents reported depression symptoms using a 4-item Likert scale ranging from 0 (not at all) to 3 (nearly every day). Nine questions assessed depression levels over the past weeks, with a total score ranged from 0 to 27 (i.e., normal $=0-4 ;$ mild $=5-9$; moderate $=10-14$; moderate to severe $=15-19$; and severe $=20-27$ ). The questions inquired about little interest or pleasure in doing things; feeling down, depressed, or hopeless; trouble falling or staying asleep, or sleeping too; feeling tired or having little energy; poor appetite or overeating; feeling bad about yourself-or that you are a failure or have let yourself or family down; trouble concentrating on things, such as reading the newspaper or watching TV; moving or speaking so slowly that other people could have or the opposite; and thoughts that you would be better off dead or of hurting $[2,28]$.

\section{Ethics approval and consent}

This study was conducted in accordance with the Declaration of Helsinki and was approved by the ethics committee of the Ministry of Health Standing Committee for Health Research. Electronic informed consent was obtained from each respondent prior to starting the investigation. Participants could withdraw from the survey at any time without providing any reason.

\section{Statistical analysis}

Descriptive analyses were applied to describe the sociodemographic characteristics, PA status, and levels of anxiety and depression among members of the Kuwaiti population during the COVID-19 outbreak. The data is presented in mean $\pm \mathrm{SD}$, frequency, or percentages. A chi-square test $\left(x^{2}\right)$ was used to compare the differences in symptoms of anxiety and depression between groups. In addition, multiple regression models were performed to investigate the potential predictors for anxiety and depression symptoms during the COVID-19 outbreak in Kuwait. All data were analyzed using Statistical Package for Social Sciences (SPSS) version 25.0. A two-tailed $P$ value $<0.05$ was considered statistically significant.

\section{Results}

\section{Sociodemographic characteristics and physical activity status}

The sociodemographic characteristics and the PA status of the respondents are shown in Table 1. A total of 1284
Table 1 Sociodemographic characteristics stratified by physical activity (PA) status during the outbreak of COVID-19 in Kuwait

\begin{tabular}{|c|c|c|c|c|c|c|}
\hline \multicolumn{2}{|l|}{$\begin{array}{l}\text { Sociographic } \\
\text { characteristics }\end{array}$} & $\begin{array}{l}N= \\
1284\end{array}$ & $\begin{array}{l}\text { Inactive } \\
693 \\
53.9 \%\end{array}$ & $\begin{array}{l}\text { Active } \\
591 \\
46.1 \%\end{array}$ & $x^{2}$ & $\begin{array}{l}P \\
\text { value }\end{array}$ \\
\hline \multirow[t]{4}{*}{ Gender } & Male & 707 & 366 & 341 & 3.08 & 0.079 \\
\hline & & $55.1 \%$ & $51.8 \%$ & $48.2 \%$ & & \\
\hline & Female & 577 & 327 & 250 & & \\
\hline & & $44.9 \%$ & $56.7 \%$ & $43 \%$ & & \\
\hline \multirow[t]{4}{*}{ Marital Status } & Unmarried & 608 & 312 & 296 & 3.28 & 0.07 \\
\hline & & $47.4 \%$ & $51.3 \%$ & $48.7 \%$ & & \\
\hline & Married & 676 & 381 & 295 & & \\
\hline & & $52.6 \%$ & $56.4 \%$ & $43.6 \%$ & & \\
\hline \multirow[t]{8}{*}{ Education } & HS \& Less & 110 & 66 & 44 & 18.692 & $<0.001$ \\
\hline & & $8.6 \%$ & $60.0 \%$ & $40.0 \%$ & & \\
\hline & Diploma & 165 & 100 & 65 & & \\
\hline & & $12.9 \%$ & $60.6 \%$ & $39.4 \%$ & & \\
\hline & Bachelor's & 759 & 421 & 338 & & \\
\hline & & $59.1 \%$ & $55.5 \%$ & $44.5 \%$ & & \\
\hline & MS or PhD & 250 & 106 & 144 & & \\
\hline & & $19.5 \%$ & $42.4 \%$ & $57.6 \%$ & & \\
\hline \multirow[t]{8}{*}{ Occupation } & Employer & 286 & 154 & 132 & 7.498 & 0.058 \\
\hline & & $22.3 \%$ & $53.8 \%$ & $46.2 \%$ & & \\
\hline & Student & 874 & 458 & 416 & & \\
\hline & & $68.1 \%$ & $52.4 \%$ & $47.6 \%$ & & \\
\hline & Retired & 67 & 45 & 22 & & \\
\hline & & $5.2 \%$ & $67.2 \%$ & $32.8 \%$ & & \\
\hline & Unemployed & 57 & 36 & 21 & & \\
\hline & & $4.4 \%$ & $63.2 \%$ & $36.8 \%$ & & \\
\hline
\end{tabular}

participants were included in the analysis. Of the 1284, $55.1 \%$ were males, $96.6 \%$ Kuwaitis, $52.6 \%$ married, 59.1\% holding a bachelor's degree, $68.1 \%$ were students, and the mean (SD) age was $33.44 \pm 11.09$ years. Among all respondents, $53.9 \%$ were inactive, while $46.1 \%$ were physically active.

\section{Prevalence of anxiety}

Table 2 shows that the anxiety score of $46.34 \%$ of respondents fell within normal range (GAD-7 $=0-4$ ); $53.66 \%$ of respondents recorded scores indicative of anxiety (GAD-7 $=5-21)$. In addition, the data showed that moderate and vigorous PA during the COVID-19 outbreak was significantly associated $(P<0.001)$ with anxiety. There was significant difference in the prevalence of anxiety between physically active and physically inactive people; there was also a significant difference in the prevalence of anxiety by gender $(P<0.001)$, and the prevalence of anxiety was significantly higher among college students $(P<0.006)$. 
Table 2 Prevalence of generalized anxiety disorder (GAD-7) among groups during the outbreak of COVID-19 in Kuwait

\begin{tabular}{|c|c|c|c|c|c|c|c|c|}
\hline \multicolumn{2}{|c|}{ Sociodemographic characteristics } & \multicolumn{4}{|c|}{ Levels of anxiety } & \multirow{4}{*}{$\begin{array}{l}\text { Anxious } \\
689 \\
53.66 \%\end{array}$} & \multirow[t]{4}{*}{$x^{2}$} & \multirow{4}{*}{$\begin{array}{l}P \\
\text { value }\end{array}$} \\
\hline & & \multirow{3}{*}{$\begin{array}{l}\text { Normal } \\
595 \\
46.34 \%\end{array}$} & \multirow{3}{*}{$\begin{array}{l}\text { Mild } \\
395 \\
30.76 \%\end{array}$} & \multirow{3}{*}{$\begin{array}{l}\text { Moderate } \\
150 \\
11.68 \%\end{array}$} & \multirow{3}{*}{$\begin{array}{l}\text { Severe } \\
144 \\
11.21 \%\end{array}$} & & & \\
\hline & & & & & & & & \\
\hline & & & & & & & & \\
\hline \multirow[t]{4}{*}{ Physical activity } & Physically inactive & 287 & 211 & 92 & 103 & 406 & 29.068 & $<0.001$ \\
\hline & & $41.40 \%$ & $30.40 \%$ & $13.30 \%$ & $14.90 \%$ & $58.6 \%$ & & \\
\hline & Physically active & 308 & 184 & 58 & 41 & 283 & & \\
\hline & & $41.40 \%$ & $30.40 \%$ & $13.30 \%$ & $14.90 \%$ & $47.9 \%$ & & \\
\hline \multirow[t]{4}{*}{ Gender } & Female & 224 & 172 & 84 & 97 & 353 & 49.772 & $<0.001$ \\
\hline & & $38.80 \%$ & $29.80 \%$ & $14.60 \%$ & $16.80 \%$ & $61.2 \%$ & & \\
\hline & Male & 371 & 223 & 66 & 47 & 336 & & \\
\hline & & $52.50 \%$ & $31.50 \%$ & $9.30 \%$ & $6.60 \%$ & $47.5 \%$ & & \\
\hline \multirow[t]{8}{*}{ Education } & High school and less & 49 & 32 & 13 & 16 & 61 & 22.968 & 0.006 \\
\hline & & $44.50 \%$ & $29.10 \%$ & $11.80 \%$ & $14.50 \%$ & $55.5 \%$ & & \\
\hline & Diploma & 64 & 46 & 34 & 21 & 101 & & \\
\hline & & $38.80 \%$ & $27.90 \%$ & $20.60 \%$ & $12.70 \%$ & $61.2 \%$ & & \\
\hline & Bachelor's degree & 351 & 244 & 76 & 88 & 408 & & \\
\hline & & $46.20 \%$ & $32.10 \%$ & $10.00 \%$ & $11.60 \%$ & $53.8 \%$ & & \\
\hline & Higher education & 131 & 73 & 27 & 19 & 119 & & \\
\hline & & $52.40 \%$ & $29.20 \%$ & $10.80 \%$ & $7.60 \%$ & $47.6 \%$ & & \\
\hline \multirow[t]{4}{*}{ Marital status } & Single & 261 & 204 & 72 & 71 & 347 & 6.068 & 0.108 \\
\hline & & $42.90 \%$ & $33.60 \%$ & $11.80 \%$ & $11.70 \%$ & $57.1 \%$ & & \\
\hline & Married & 334 & 191 & 78 & 73 & 342 & & \\
\hline & & $49.40 \%$ & $28.30 \%$ & $11.50 \%$ & $10.80 \%$ & $50.6 \%$ & & \\
\hline \multirow[t]{8}{*}{ Occupation } & Employer & 126 & 88 & 36 & 36 & 160 & 15.884 & 0.069 \\
\hline & & $44.10 \%$ & $30.80 \%$ & $12.60 \%$ & $12.60 \%$ & $55.9 \%$ & & \\
\hline & Student & 405 & 272 & 99 & 98 & 469 & & \\
\hline & & $46.30 \%$ & $31.10 \%$ & $11.30 \%$ & $11.20 \%$ & $53.7 \%$ & & \\
\hline & Retired & 44 & 13 & 5 & 5 & 23 & & \\
\hline & & $65.70 \%$ & $19.40 \%$ & $7.50 \%$ & $7.50 \%$ & $34.3 \%$ & & \\
\hline & Unemployed & 20 & 22 & 10 & 5 & 37 & & \\
\hline & & $35.10 \%$ & $38.60 \%$ & $17.50 \%$ & $8.80 \%$ & $64.9 \%$ & & \\
\hline
\end{tabular}

The designation of "anxious" represents respondents who scored 5 to 21 in GAD-7 scale (i.e., mild, moderate, and severe anxiety); \% within independent variable groups

\section{Prevalence depression}

Table 3 shows that $40.42 \%$ of respondents scored within the normal range for depression levels (PHQ-9 =0-4); $59.6 \%$ were considered to suffer from depression (PHQ$9=5-27)$. Table 3 also demonstrates that PA moderate and vigorous during the COVID-19 outbreak was significantly associated $(P<0.001)$ with depression. There was significant difference in the prevalence of depression between physically active and physically inactive people; there was also a significant difference in the prevalence of depression by gender $(P<0.001)$, and the prevalence of depression was significantly higher among college students $(P<0.003)$. Unlike anxiety, the prevalence of depression was significantly associated with marital status and occupation, as there was a significant difference in depression levels between married and single respondents, and between students and others $(P<0.001)$.

\section{Predictors of anxiety}

Multiple regression models were performed for the continuous variables of anxiety score $(M=6.26 \pm 5.5)$. A multicollinearity test was carried out to verify the existence of the association, and the result revealed that the VIF factor of the model was $<3$, indicating no multicollinearity [10]. The residuals of both models were normally distributed [3] (see Appendix). The associations of potential predictors of anxiety during COVID-19 are presented in Table 4. 
Table 3 Prevalence of depression (PHQ-9) among groups during the outbreak of COVID-19 in Kuwait

\begin{tabular}{|c|c|c|c|c|c|c|c|c|c|}
\hline \multicolumn{2}{|c|}{ Sociodemographic characteristics } & \multicolumn{5}{|c|}{ Depression level } & \multirow{4}{*}{$\begin{array}{l}\text { Depressed } \\
765 \\
59.6 \%\end{array}$} & \multirow[t]{4}{*}{$x^{2}$} & \multirow{4}{*}{$\begin{array}{l}P \\
\text { value }\end{array}$} \\
\hline & & \multirow{3}{*}{$\begin{array}{l}\text { Normal } \\
519 \\
40.42 \%\end{array}$} & \multirow{3}{*}{$\begin{array}{l}\text { Mild } \\
399 \\
31.07 \%\end{array}$} & \multirow{3}{*}{$\begin{array}{l}\text { Moderate } \\
199 \\
15.50 \%\end{array}$} & \multirow{3}{*}{$\begin{array}{l}\text { Moderate to severe } \\
108 \\
8.41 \% \\
\end{array}$} & \multirow{3}{*}{$\begin{array}{l}\text { Severe } \\
59 \\
4.60 \%\end{array}$} & & & \\
\hline & & & & & & & & & \\
\hline & & & & & & & & & \\
\hline \multirow[t]{4}{*}{ Physical activity } & Physically inactive & 222 & 222 & 132 & 72 & 45 & 471 & 57.694 & $<0.001$ \\
\hline & & $32.00 \%$ & $32.00 \%$ & $19.00 \%$ & $10.40 \%$ & $6.50 \%$ & $68.0 \%$ & & \\
\hline & Physically active & 297 & 177 & 67 & 36 & 14 & 294 & & \\
\hline & & $50.30 \%$ & $29.90 \%$ & $11.30 \%$ & $6.10 \%$ & $2.40 \%$ & $49.7 \%$ & & \\
\hline \multirow[t]{4}{*}{ Gender } & Female & 176 & 176 & 102 & 81 & 42 & 401 & 84.697 & $<0.001$ \\
\hline & & $30.50 \%$ & $30.50 \%$ & $17.70 \%$ & $14.00 \%$ & $7.30 \%$ & $69.5 \%$ & & \\
\hline & Male & 343 & 223 & 97 & 27 & 17 & 364 & & \\
\hline & & $48.50 \%$ & $31.50 \%$ & $13.70 \%$ & $3.80 \%$ & $2.40 \%$ & $51.5 \%$ & & \\
\hline \multirow[t]{8}{*}{ Education } & High school and less & 43 & 29 & 19 & 14 & 5 & 67 & 29.642 & 0.003 \\
\hline & & $39.10 \%$ & $26.40 \%$ & $17.30 \%$ & $12.70 \%$ & $4.50 \%$ & $60.9 \%$ & & \\
\hline & Diploma & 63 & 56 & 26 & 11 & 9 & 102 & & \\
\hline & & $38.20 \%$ & $33.90 \%$ & $15.80 \%$ & $6.70 \%$ & $5.50 \%$ & $61.8 \%$ & & \\
\hline & Bachelor's degree & 281 & 240 & 129 & 70 & 39 & 478 & & \\
\hline & & $37.00 \%$ & $31.60 \%$ & $17.00 \%$ & $9.20 \%$ & $5.10 \%$ & $63.0 \%$ & & \\
\hline & Higher education & 132 & 74 & 25 & 13 & 6 & 118 & & \\
\hline & & $52.80 \%$ & $29.60 \%$ & $10.00 \%$ & $5.20 \%$ & $2.40 \%$ & $47.2 \%$ & & \\
\hline \multirow[t]{4}{*}{ Marital status } & Single & 190 & 209 & 105 & 60 & 44 & 418 & 50.869 & $<0.001$ \\
\hline & & $31.30 \%$ & $34.40 \%$ & $17.30 \%$ & $9.90 \%$ & $7.20 \%$ & $68.8 \%$ & & \\
\hline & Married & 329 & 190 & 94 & 48 & 15 & 347 & & \\
\hline & & $48.70 \%$ & $28.10 \%$ & $13.90 \%$ & $7.10 \%$ & $2.20 \%$ & $51.3 \%$ & & \\
\hline \multirow[t]{8}{*}{ Occupation } & Employer & 73 & 102 & 54 & 37 & 20 & 213 & 61.492 & $<0.001$ \\
\hline & & $25.50 \%$ & $35.70 \%$ & $18.90 \%$ & $12.90 \%$ & $7.00 \%$ & $74.5 \%$ & & \\
\hline & Student & 379 & 272 & 131 & 62 & 30 & 495 & & \\
\hline & & $43.40 \%$ & $31.10 \%$ & $15.00 \%$ & $7.10 \%$ & $3.40 \%$ & $56.6 \%$ & & \\
\hline & Retired & 44 & 12 & 3 & 3 & 5 & 23 & & \\
\hline & & $65.70 \%$ & $17.90 \%$ & $4.50 \%$ & $4.50 \%$ & $7.50 \%$ & $34.3 \%$ & & \\
\hline & Unemployed & 23 & 13 & 11 & 6 & 4 & 34 & & \\
\hline & & $40.40 \%$ & $22.80 \%$ & $19.30 \%$ & $10.50 \%$ & $7.00 \%$ & $59.6 \%$ & & \\
\hline
\end{tabular}

"Depressed" column represents all respondents who scored 5 to 27 in PHQ-9 scale (i.e., mild, moderate, moderate to severe, and severe depression); \% within independent variable groups

A multiple regression was used to examine the relationship of anxiety with PA, gender, education, age, occupation, and/or marital status (Table 4). The regression model significantly predicted anxiety $\left(F_{(6,1277)}=18.028\right.$, $p<0.001$, adj. $\left.R^{2}=0.074, R^{2}=.279\right)$. PA, gender, education, and age added statistical significance to the prediction $(P<0.05)$. The highest beta was for gender impact $(B=2.125)$, indicating that the women experienced greater anxiety during the COVID-19 outbreak than the men. The second highest beta was for the negative impact of PA $(B=-1.507)$, indicating that respondents engaged in more PA experienced lower anxiety during the COVID-19 outbreak. This finding was followed by the negative impact of education $(B=-0.493)$ indicating lower anxiety with higher education level. The least negative impact corresponded to age $(B=-0.05)$, indicating lower anxiety levels with older age. Marital status and occupation had no significant impact on anxiety during the COVID-19 outbreak in Kuwait $(P>0.05)$.

\section{Predictors of depression}

Multiple regression models were performed for the continuous variables of depression score $(M=7.20 \pm 5.9)$. A multicollinearity test was carried out to verify the existence of the association, and the result revealed that the VIF factor of the model was $<3$, indicating no 
Table 4 Multiple regression results for anxiety

\begin{tabular}{|c|c|c|c|c|c|c|c|}
\hline \multirow[t]{2}{*}{ Anxiety } & \multirow[t]{2}{*}{$B$} & \multicolumn{2}{|c|}{$95 \% \mathrm{Cl}$ for $\mathrm{B}$} & \multirow[t]{2}{*}{ SE B } & \multirow[t]{2}{*}{$\beta$} & \multirow[t]{2}{*}{$R 2$} & \multirow[t]{2}{*}{$A R 2$} \\
\hline & & LL & UL & & & & \\
\hline Model & & & & & & 0.078 & $0.074^{* * *}$ \\
\hline (Constant) & $14.18^{* * *}$ & 12.323 & 16.042 & 0.948 & & & \\
\hline Gender & $-2.125^{* * *}$ & -2.719 & -1.531 & 0.30 & $-0.192^{* * *}$ & & \\
\hline Physical activity & $-1.507^{* * *}$ & -2.096 & -0.919 & 0.30 & $-0.136^{* * *}$ & & \\
\hline Education & $-0.493^{* *}$ & $-.865-$ & -0.121 & 0.19 & $-0.072^{* *}$ & & \\
\hline Age & $-.0500^{* *}$ & -0.084 & -0.015 & 0.018 & $-0.1^{* *}$ & & \\
\hline Marital status & 0.381 & -0.343 & 1.104 & 0.369 & 0.035 & & \\
\hline Occupation & 0.045 & -0.436 & 0.527 & 0.246 & 0.006 & & \\
\hline
\end{tabular}

Note. Model "Enter" method in SPSS Statistics; $B$ unstandardized regression coefficient; $C l$ confidence interval; $L L$ lower limit; UL upper limit; SE B standard error of the coefficient; $\beta$ standardized coefficient; $R 2$ coefficient of determination; AR2 adjusted R2; ${ }^{*} p<>.05,{ }^{* *} p<.01,{ }^{* * *} p<.001$

multicollinearity [10]. The residuals of both models were normally distributed [3] (see Appendix) The potential predictors of depression during COVID-19 are presented in Table 5.

In addition, a multiple regression was used to examine the relationship of depression with PA, gender, education, age, occupation, and/or marital status (Table 5). The regression model significantly predicted depression $\left(F_{(6,1277)}=38.004, P<.001\right.$, adj. $\left.R^{2}=0.152, R^{2}=0.389\right)$. $\mathrm{PA}$, gender, age, and marital status added statistical significance to the prediction, $P<0.05$. The highest beta $(B)$, at 2.534, was for gender impact, as women experienced higher levels of depression than men. The second highest beta was for the negative impact of PA $(B=$ 2.436), indicating that respondents who engaged in higher levels of PA experienced lower levels of depression. This finding was followed by the impact of marital status $(B=0.965)$; married respondents indicated higher levels of depression than single respondents. Finally, the least negative impact was for age $(B=0.069)$, indicating that respondents older in age experienced the lowest levels of depression. Education and occupation variables

Table 5 Multiple regression results for depression

\begin{tabular}{|c|c|c|c|c|c|c|}
\hline \multirow[t]{2}{*}{ Depression } & \multirow[t]{2}{*}{$B$} & \multicolumn{2}{|c|}{$95 \% \mathrm{Cl}$ for $B$} & \multirow[t]{2}{*}{$S E B$} & \multirow[t]{2}{*}{$\beta$} & \multirow[t]{2}{*}{$R 2$} \\
\hline & & $L L$ & $U L$ & & & \\
\hline Model & & & & & & 0.152 \\
\hline (Constant) & $19.648^{* * *}$ & 17.75 & 21.546 & 0.97 & & \\
\hline Gender & $-2.534^{* * *}$ & -3.140 & -1.927 & 0.31 & $-.215^{* * *}$ & \\
\hline Physical Activity & $-2.436^{* * *}$ & -3.036 & -1.835 & 0.31 & $-.207^{* * *}$ & \\
\hline Marital Status & $-0.965^{*}$ & -1.703 & -0.226 & 0.376 & -0.082 & \\
\hline Age & $-.069^{* * *}$ & -0.104 & -0.034 & 0.018 & -0.13 & \\
\hline Occupation & 0.249 & -0.741 & 0.243 & 0.251 & -0.028 & \\
\hline Education & -0.244 & -0.624 & 0.136 & 0.194 & -0.034 & \\
\hline
\end{tabular}

Note. Model "Enter" method in SPSS Statistics; $B$ unstandardized regression coefficient; $C l$ confidence interval; $L L$ lower limit; UL upper limit; SE B standard error of the coefficient; $\beta$ standardized coefficient; $R 2$ coefficient of determination; AR2 adjusted R2; ${ }^{*} p<>.05,{ }^{* *} p<.01,{ }^{* * *} p<.001$ had no significant impact on levels of depression among the population of Kuwait during the COVID-19 outbreak $(P>0.05)$.

\section{Discussion}

This study examined the prevalence and predictors of anxiety and depression during the COVID-19 outbreak in Kuwait. The data showed that over half of the participants reported anxiety, while close to $60 \%$ reported depression during the COVID-19 outbreak. According to the results, symptoms of anxiety were more likely to appear in women and individuals with lower PA and education and who are younger while symptoms of depression were more prevalent among women, elderly, and individuals with lower level of PA and education and who are married. These findings confirm psychological effects of COVID-19 as the results from recent studies from China [15, 19, 31] and Australia [29]

In agreement with recent findings $[9,15]$, younger respondents showed greater levels of anxiety and depression during the COVID-19 outbreak in Kuwait. Although the reasons for this are complex, it may be due to that this segment of population were most exposed to news from social media, which is usually overwhelmed with fake news, unconfirmed information, and rumors [19, 21]. Additionally, suspending schools, colleges, and university in Kuwait might have imposed feelings of loneliness, boredom, uncertainty, and stress [26]. These negative feelings are usually associated adverse psychological implications including anxiety and depression.

In agreement with previous studies [13, 14, 31], and in contrast to others [15], women in the current study suffered from anxiety and depression at greater levels than men during the COVID-19 outbreak. Liu et al. [19] indicated that these psychological differences might be because women are more sensitive to psychological stress thus susceptible to experiencing anxiety and depression versus men $[18,31]$. Greater prevalence of anxiety and depression might also be attributed to lower PA 
participation among women. Although Kuwait has experienced rapid social development, including more opportunities for women to exercise while maintaining privacy, cultural barriers often prevent women from sufficient PA participation. In accordance with previous research [1, 32], less women were physically active compared to men, although the difference was nonsignificant in the current study (Table 1). Furthermore, given the family responsibilities, women were most likely to stay home with the children during the 2-h gross period, which is an important outlet for stress relief.

More than $50 \%$ of the respondents in the current study reported no proper PA, which is similar to previously reported (57.23\%) [1]. This might indicate that participation in PA was directly affected by COVID-19 outbreak. However, more studies are needed to verify these results and speculations. Numerous studies $[4,5]$ and meta-analyses $[24,30]$ have shown that exercise is associated with psychological benefits, including a reduction in the risk of anxiety and depression. The current findings confirmed that greater participation in PA is associated with lower anxiety and depression during the COVID-19 epidemic. The regression models showed that respondents who followed the standard PA guidelines during the COVID-19 outbreak reported normal levels of anxiety and depression (GAD-7 = 0-4; PHQ-9 $=0-4)$. This indicates the positive impact of PA during an epidemic and should serve to encourage people to become or remain active even during a total curfew. These findings suggest that the Kuwaiti government implementation of the 2-h grace period was beneficial in preventing more symptoms of anxiety and depression. Furthermore, this grace period should probably be extended a little longer for more PA engagement. Therefore, during future epidemics, stakeholders should respond rapidly and comprehensively to encourage widespread participation in PA, in or outside the home, to increase physical and mental health. These findings confirm an important point of view: While PA produces long-term benefits for mental health, it also produces immediate psychological benefits in terms of mood, anxiety, and stress [12, 27].

This is the first study to measure the prevalence of anxiety and depression during the pandemic in Kuwait. It is also the first study to examine the relationship between PA and anxiety and depression among the Kuwaiti population. Despite this, the study was limited by its cross-sectional nature, which challenges conclusions about long-term effects. It was also limited by the online survey, which may have prevented some people from participating (although, it should be noted, an online survey is one of few ways to reach people during total curfew measures). Additional limitation to be considered is the assessment of physical activity. A conventional PA questionnaire was not used in order to preserve the respondents' time for the other questionnaires (i.e., PHQ-9 and GAD-7). The survey was conducted from 21 June to 11 July, and around that time over 158,000 expatriates have left Kuwait. This may explain the shortage of nonKuwaiti respondents in this study.

\section{Conclusion}

Consistent with hypothesis, findings of this study suggest that the COVID-19 outbreak may have greater psychological impact on women, younger and married individuals, and individuals with a lower level of education. However, regular PA appears to be an important longterm and immediate factor in reducing symptoms of anxiety and depression during an epidemic.

\section{Supplementary Information}

The online version contains supplementary material available at https://doi. org/10.1186/s43045-020-00065-6.

Additional file 1. Appendix A.

Abbreviations

PA: Physical activity; GAD-7: Generalized anxiety disorder; PHQ: Patient Health Questionnaire; PHQ-9: It is a module in PHQ which measures depression symptoms; PAAET: Public Authority for Applied Education and Training

\section{Acknowledgements}

Not applicable.

\section{Ethics approval and consent of participants}

This study was conducted in accordance with the Declaration of Helsinki and was approved by the ethics committee of the Ministry of Health Standing Committee for Health Research. Electronic informed consent was obtained from each respondent prior to starting the investigation. Participants could withdraw from the survey at any time without providing any reason (please see supplementary materials)

Author's contributions

The author read and approved the final manuscript.

\section{Funding}

Not applicable.

Availability of data and materials

The datasets used and/or analyzed during the current study are available from the corresponding author on reasonable request.

Consent for publication

Not applicable.

\section{Competing interests}

The authors declare that they have no competing interests.

Received: 10 September 2020 Accepted: 15 October 2020

Published online: 03 November 2020

References

1. Al-Baho AK, Al-Naar A, Al-Shuaib H, Panicker JK, Gaber S (2016) Levels of physical activity among Kuwaiti adults and perceived barriers. Open Public Health J 9(1):77-87. https://doi.org/10.2174/1874944501609010077

2. AlHadi AN, AlAteeg DA, Al-Sharif E, Bawazeer HM, Alanazi H, AlShomrani AT, Shuqdar RM, AlOwaybil R (2017) An arabic translation, reliability, and validation of patient health questionnaire in a Saudi sample. Ann General Psychiatry 16(1):1-9 https://doi.org/10.1186/s12991-017-0155-1 
3. Altman DG, Bland JM (1983) Measurement in medicine: the analysis of method comparison studies. Statistician 32(3):307-317 https://doi.org/10. 2307/2987937

4. Anderson E, Shivakumar G (2013) Effects of exercise and physical activity on anxiety. Front Psychiatry 4(27):1-4 https://doi.org/10.3389/fpsyt.2013.00027

5. Asmundson GJG, Fetzner MG, Deboer LB, Powers MB, Otto MW, Smits JAJ (2013) Let's get physical: a contemporary review of the anxiolytic effects of exercise for anxiety and its disorders. Depress Anxiety 30(4):362-373 https:// doi.org/10.1002/da.22043

6. Bi K, Chen Y, Zhao S, Ben-Arieh D, Wu CH(J) (2019) Modeling learning and forgetting processes with the corresponding impacts on human behaviors in infectious disease epidemics. Comput Ind Eng 129:563-577 https://doi. org/10.1016/j.cie.2018.04.035

7. Calati R, Ferrari C, Brittner M, Oasi O, Olié E, Carvalho AF, Courtet P (2019) Suicidal thoughts and behaviors and social isolation: a narrative review of the literature. J Affect Disord 245:653-667 https://doi.org/10.1016/j.jad.2018. 11.022

8. Callaghan P (2004) Exercise: a neglected intervention in mental health care? J Psychiatr Ment Health Nurs 11(4):476-483 https://doi.org/10.1111/j.13652850.2004.00751.x

9. Cao W, Fang Z, Hou G, Han M, Xu X, Dong J, Zheng J (2020) The psychological impact of the COVID-19 epidemic on college students in China. Psychiatry Res 287:112934 https://doi.org/10.1016/j.psychres.2020. 112934

10. Chatterjee S, Price B (1991) Regression diagnostics. John Wiley, New York

11. Chekroud SR, Gueorguieva R, Zheutlin AB, Paulus M, Krumholz HM, Krystal $\mathrm{JH}$, Chekroud AM (2018) Association between physical exercise and mental health in 1.2 million individuals in the USA between 2011 and 2015: a crosssectional study. Lancet Psychiatry 5(9):739-746 https://doi.org/10.1016/ S2215-0366(18)30227-X

12. Fleming KM, Campbell M, Herring MP (2020) Acute effects of Pilates on mood states among young adult males. Complement Ther Med 49:102313 https://doi.org/10.1016/j.ctim.2020.102313

13. Gao W, Ping S, Liu X (2020) Gender differences in depression, anxiety, and stress among college students: a longitudinal study from China. J Affect Disord 263:292-300 https://doi.org/10.1016/j.jad.2019.11.121

14. Guo X, Meng Z, Huang G, Fan J, Zhou W, Ling W, Jiang J, Long J, Su L (2016) Meta-analysis of the prevalence of anxiety disorders in mainland China from 2000 to 2015. Sci Rep 6(1):1-15 https://doi.org/10.1038/ srep28033

15. Huang Y, Zhao N (2020) Generalized anxiety disorder, depressive symptoms and sleep quality during COVID-19 outbreak in China: a web-based crosssectional survey. Psychiatry Res 288:112954 https://doi.org/10.1016/j. psychres.2020.112954

16. Kandola A, Ashdown-Franks G, Hendrikse J, Sabiston CM, Stubbs B (2019) Physical activity and depression: towards understanding the antidepressant mechanisms of physical activity. Neurosci Biobehav Rev 107:525-539 https://doi.org/10.1016/j.neubiorev.2019.09.040

17. Katula JA, Blissmer BJ, McAuley E (1999) Exercise intensity and self-efficacy effects on anxiety reduction in healthy, older adults. J Behav Med 22(3):233247 https://doi.org/10.1023/A:1018768423349

18. Lim GY, Tam WW, Lu Y, Ho CS, Zhang MW, Ho RC (2018) Prevalence of depression in the community from 30 countries between 1994 and 2014 Sci Rep 8(1):1-10 https://doi.org/10.1038/s41598-018-21243-X

19. Liu X, Luo WT, Li Y, Li CN, Hong ZS, Chen HL, Xiao F, Xia JY (2020) Psychological status and behavior changes of the public during the COVID19 epidemic in China. Infect Dis Poverty 9(1):1-11 https://doi.org/10.1186/ s40249-020-00678-3

20. López-Bueno R, Calatayud J, Casaña J, Casajús JA, Smith L, Tully MA, Andersen LL, López-Sánchez GF (2020) COVID-19 confinement and health risk behaviors in Spain. Front Psychol 11:1426 https://doi.org/10.3389/fpsyg. 2020.01426

21. Moustafa AA, Tindle R, Frydecka D, Misiak B (2017) Impulsivity and its relationship with anxiety, depression and stress. Compr Psychiatry 74:173179 https://doi.org/10.1016/j.comppsych.2017.01.013

22. Petruzzello SJ, Landers DM, Hatfield BD, Kubitz KA, Salazar W (1991) A metaanalysis on the anxiety-reducing effects of acute and chronic exercise: outcomes and mechanisms. Sports Med 11(3):143-182 https://doi.org/10. 2165/00007256-199111030-00002

23. Rajeswari S, Sanjeevareddy N (2020) Efficacy of progressive muscle relaxation on pregnancy outcome among anxious Indian primi mothers.
Iran J Nurs Midwifery Res 25(1):23-30 https://doi.org/10.4103/ijnmr.IJNMR_ 207_18

24. Rebar AL, Stanton R, Geard D, Short C, Duncan MJ, Vandelanotte C (2015) A meta-meta-analysis of the effect of physical activity on depression and anxiety in non-clinical adult populations. Health Psychol Rev 9(3):366-378 https://doi.org/10.1080/17437199.2015.1022901

25. Saadatian-Elahi M, Facy F, Del Signore C, Vanhems P (2010) Perception of epidemic's related anxiety in the general French population: a crosssectional study in the Rhne-Alpes region. BMC Public Health 10(1):1-10 https://doi.org/10.1186/1471-2458-10-191

26. Santini ZI, Jose PE, York Cornwell E, Koyanagi A, Nielsen L, Hinrichsen C, Meilstrup C, Madsen KR, Koushede V (2020) Social disconnectedness, perceived isolation, and symptoms of depression and anxiety among older Americans (NSHAP): a longitudinal mediation analysis. Lancet Public Health 5(1):e62-e70 https://doi.org/10.1016/S2468-2667(19)30230-0

27. Smits JAJ, Berry AC, Rosenfield D, Powers MB, Behar E, Otto MW (2008) Reducing anxiety sensitivity with exercise. Depress Anxiety 25(8):689-699 https://doi.org/10.1002/da.20411

28. Spitzer RL, Kroenke K, Williams JBW (1999) Validation and utility of a selfreport version of PRIME-MD: the PHQ primary care study. J Am Med Assoc 282(18):1737-1744 https://doi.org/10.1001/jama.282.18.1737

29. Stanton R, To, Q. G, Khalesi S, Williams SL, Alley SJ, Thwaite TL, Fenning AS, Vandelanotte C (2020) Depression, anxiety and stress during COVID-19: associations with changes in physical activity, sleep, tobacco and alcohol use in Australian adults. Int J Environ Res Public Health 17(11):1-13 https:// doi.org/10.3390/ijerph17114065

30. Stubbs B, Vancampfort D, Rosenbaum S, Firth J, Cosco T, Veronese N, Salum GA, Schuch FB (2017) An examination of the anxiolytic effects of exercise for people with anxiety and stress-related disorders: a meta-analysis. Psychiatry Res 249:102-108 https://doi.org/10.1016/j.psychres.2016.12.020

31. Wang C, Pan R, Wan X, Tan Y, Xu L, Ho CS, Ho RC (2020) Immediate psychological responses and associated factors during the initial stage of the 2019 coronavirus disease (COVID-19) epidemic among the general population in China. Int J Environ Res Public Health 17(5):1729 https://doi. org/10.3390/ijerph17051729

32. Weiderpass E, Botteri E, Longenecker JC, Alkandari A, Al-Wotayan R, Al Duwairi Q, Tuomilehto J (2019) The prevalence of overweight and obesity in an adult Kuwaiti population in 2014. Front Endocrinol 10:449 https://doi. org/10.3389/fendo.2019.00449

33. World Health Organization (2010) Global recommendations on physical activity for health. Switzerland, Geneva

34. Zhu N, Zhang D, Wang W, Li X, Yang B, Song J, Zhao X, Huang B, Shi W, Lu R, Niu P, Zhan F, Ma X, Wang D, Xu W, Wu G, Gao GF, Tan W (2020) A novel coronavirus from patients with pneumonia in China, 2019. N Engl J Med 382(8):727-733 https://doi.org/10.1056/NEJMoa2001017

\section{Publisher's Note}

Springer Nature remains neutral with regard to jurisdictional claims in published maps and institutional affiliations.

\section{Submit your manuscript to a SpringerOpen ${ }^{\circ}$ journal and benefit from:}

- Convenient online submission

- Rigorous peer review

- Open access: articles freely available online

- High visibility within the field

- Retaining the copyright to your article

Submit your next manuscript at $>$ springeropen.com 